\title{
Optimiziranje tehnološkog procesa uvijanja dvonavojinih matica
}

\section{Optimization of Double Thread Nuts Screwing Process}

\author{
Izvorni znanstveni rad • Original scientific paper \\ Prispjelo-received: 24. 9. 2010. \\ Prihvaćeno-accepted: 9. 2. 2012. \\ UDK: $630 * 824.23 ; 630 * 836 ; 674.23$ \\ doi:10.5552/drind.2012.1031
}

\begin{abstract}
SAŽETAK • U konstrukcijama namještaja ugaoni se sklopovi često izvode sastavljanjem uz pomoć dvonavojnih (,,trio“) matica i metalnih kutnika. Takvi su sklopovi posebice pogodni za konstrukcije koje je potrebno rastavljati ili se takvim sklopom ostvaruje ušteda pri transportu, kada se svi elementi konstrukcije prevoze u kutijama, a namještaj se sastavlja na mjestu upotrebe. Proces sastavljanja konstrukcije sastoji se od pritezanja veznih metalnih kutnika za drvene elemente vijcima metričkog navoja. Za postizanje optimalne kvalitete takvih sklopova proces proizvodnje mora biti usklađen sa zahtjevima različitih proizvoda, što podrazumijeva načine opterećivanja i čvrstoće pojedinih vrsta drva. U ovom su radu istraženi osnovni čimbenici koji utječu na kvalitetu te vrste sklopa. Posebna je pozornost pridana procesu uvijanja te sili izvlačenja dvonavojnih matica na trima različitim vrstama drva. Kao krajnji cilj postavljena je optimizacija tehnološkog procesa kojim se u proizvodnji može postići visoka razina kvalitete proizvoda.

Ispitivanjima na jelovini, bukovini i hrastovini utvrđeni su optimalni provrti rupa i parametri uvijanja matica s obzirom na otpor uvijanja, silu izvlačenja i vremenski interval potreban za uvijanje.
\end{abstract}

Ključne riječi: metalni kutnici, dvonavojne matice, moment uvijanja, utrošak vremena, sila izvlačenja

\begin{abstract}
The construction of furniture corner joints is often carried out by assembling double thread ("Trio") nuts and metal corners. Such connections are particularly suitable for disassemble bal structures and these connections are also used for savings in transport when all the structural elements are transported in boxes and furniture is prepared for in site assembly. The assembly process consists of fastening the binding metal corners to wooden elements with the metric thread screws. To achieve the optimal quality of these joints, the production process must comply with the requirements of various products including the loading applications and strength of individual wood species. This paper examines the fundamental factors affecting the quality of such joints. Special attention was paid to the process of screwing and loading capacity of double thread nuts in three different types of wood. Optimization of the technological process was set as the ultimate goal aimed at achieving a high level of product quality.

Tests have been conducted on fir, beech and oak wood to determine optimal bore diameters and nut screwing parameters relative to the screwing resistance, extraction force and the time interval required for nut screwing.
\end{abstract}

Keywords: metal angles, double thread nuts, screwing moment, time saving, extraction strength

\footnotetext{
${ }^{1}$ Autori su docent i student Šumarskog fakulteta Sveučilišta u Zagrebu, Zagreb, Hrvatska. ${ }^{2}$ Autor je zaposlenik tvrke Drvodjelac d.o.o. Ivanec, Hrvatska.

${ }^{1}$ Authors are assistant professor and student of Faculty of Forestry, University of Zagreb, Zagreb, Croatia. ${ }^{2}$ Author is an employee of the company Drvodjelac d.o.o. Ivanec, Croatia.
} 


\section{UVOD}

\section{INTRODUCTION}

U današnje vrijeme svoj životni prostor sve više prilagođujemo vlastitim željama i uređujemo ga prema raznovrsnim dizajnerskim rješenjima. Razvojem dizajna i načina razmišljanja ljudi se više ne žele prilagođivati onome što nameću proizvodnja namještaja i njezina ograničena ponuda (Grbac i Ivelić, 2005).

Stoga su fleksibilnost proizvodnje i sposobnost brze prilagodbe promjenama potražnje uvjeti koje treba ispuniti želimo li se održati na tržištu. Prilagodba proizvodnje namještaja tim uvjetima može se postići vrednovanjem rješenja dobivenih metodičkim pristupom (Tkalec, 1983) koji se, među ostalim, može ostvariti:

- uvođenjem nove tehnologije

- primjenom boljih konstrukcijskih rješenja uz postojeću tehnologiju.

Jedan od primjera prilagodbe proizvodnje primjenom boljih konstrukcijskih rješenja jest unifikacija veznog sastavljanja primjenom metalnih kutnika. Drveni se elementi pri tome međusobno povezuju metalnim kutnicima, bez obzira na oblike i namjenu krajnjeg proizvoda. Takav način vezanja omogućuje jednostavnu i brzu montažu, a metalnim se kutnicima ujedno osigurava čvrst i trajan sastav.

Dvonavojne matice, tzv. trio matice, uviju se u drvene elemente te se zatim za njih vijcima metričkog navoja učvrste metalni kutnici. Time je dobiven kvalitetan spoj koji ne nameće velike zahtjeve pri montaži.

Postoji više vrsta dvonavojnih matica za drvo koje se mogu svrstati u vezne elemente (Tkalec i Prekrat, 2000). Njihova se nosivost temelji na povećanom promjeru vanjskog navoja koji sam narezuje ležište u drvnim materijalima. Za sve matice karakteristična je izvedba unutarnjega metričkog navoja koja omogućuje upotrebu standardnih vijaka pri sastavljanju drvenih elemenata. Različitosti matica očituju se različito izvedenim vanjskim navojima. Oni bi trebali biti prilagođeni
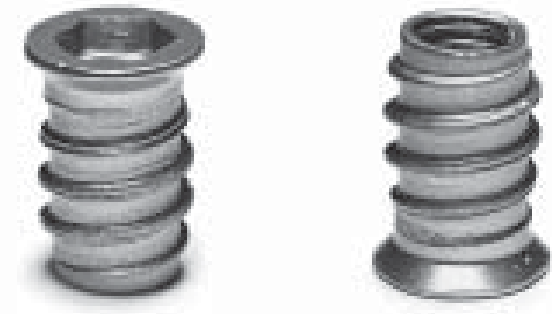

Slika 1. Dvonavojne matice ravnoga ureznog navoja Figure 1 Flat double thread nuts svojstvima materijala u koji se uvijaju. Tako neki proizvođači nude matice s klasičnim navojem za drvo koji su uvećana slika ravnih vijaka, dok drugi nude konusne matice čiji su navoji sličniji vijcima za drvo, koji barem u jednom svojem dijelu imaju konusni navoj za urezivanje navoja u drvu.

Osnova ugradnje takovih matica jest adekvatno izbušena rupa u drvu. Ako je promjer rupe premalen, uvijanje će biti otežano, a vanjski će navoj pri uvijanju uništiti površinu uz rupu te će time smanjiti nosivost sustava. Nasuprot tome, ako je promjer rupe prevelik, jasno je da će takav sastav biti slab jer vanjski navoj neće zadovoljavajuće zahvaćati drvni materijal i izvlačna će sila biti malena.

U radu Mihulje i suradnika (2008) rješavan je problem sastavljanja konstrukcije kreveta od bukovine pri čemu je mjestimično dolazilo do izvlačenja dvonavojne matice iz drva. Problem nedovoljne čvrstoće za promjere provrta od $11 \mathrm{~mm}$ upućivao je na potrebu smanjenja promjera provrta na $10 \mathrm{~mm}$. Međutim, smanjenjem promjera provrta pojavili su se novi problemi. Naime, pri manjim promjerima provrta potrebna je veća sila za uvijanje matica, čime se opterećuje alat za uvijanje i produljuje vrijeme potrebno za njihovo uvijanje, što izravno utječe na tijek proizvodnje. Iskustva i rezultati tih istraživanja bili su temelj za nova istraživanja kojima bi se utvrdio optimalan promjer provrta za uvijanje matice s obzirom na specifična svojstva različitih vrsta drva, momente pri uvijanju, vremenske intervale potrebne za uvijanje te na sile izvlačenja matica.

Pretpostavlja se da će upotreba svrdla za bušenje provrta promjera $10,5 \mathrm{~mm}$ osigurati smanjenje momenta uvijanja i na drugim vrstama drva, a time i skraćivanje vremena tehnološkog procesa, pri čemu se sile izvlačenja neće statistički značajno smanjiti.

\section{MATERIJALI I METODE}

\section{MATERIALS AND METHODS}

Za ovo su istraživanje odabrane tri komercijalne vrste drva: bukovina, hrastovina i jelovina kako bi se raznovrsnošću mehaničkih svojstava drva adekvatno vrednovao utjecaj urezivanja navoja u drvo. Uzorkovanje materijala obavljeno je iz skupa elemenata koji su prošli kvalitetan proces predsušenja i sušenja standardnim postupkom, a kontrolom elemenata nisu primijećeni nikakvi nedostaci ili greške koje bi sušenjem nastale.

Odabrane su dvonavojne matice ravnoga urezanog navoja koraka 3,2 mm po navoju, promjera korijena $9,5 \mathrm{~mm}$, ukupne duljine $14,5 \mathrm{~mm}$.
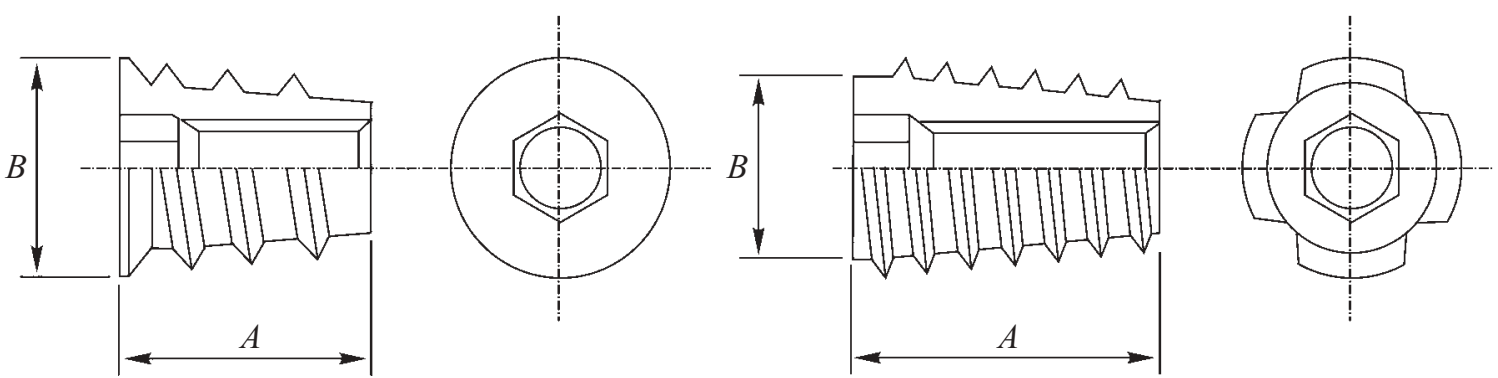

Slika 2. Dvonavojne matice konusnoga ureznog navoja

Figure 2 Tapered double thread nuts 


\subsection{Priprema uzoraka za ispitivanje}

\subsection{Preparing test samples}

Elementi bukovine, hrastovine i jelovine izdvojeni su iz složajeva slučajnim odabirom i osušeni su na vlažnost od $8-10 \%$, kondicionirani u laboratorijskim uvjetima $50 \pm 5 \%$ r.v.z. i $23 \pm 2{ }^{\circ} \mathrm{C}$, pravne žice, ujednačenih širina godova, bez vidljivih grešaka, obrađeni na četverostranoj blanjalici.

Na elementima dimenzija $300 \times 42 \times 30 \mathrm{~mm}$ bušene su rupe promjera provrta $10 \mathrm{~mm}, 10,5 \mathrm{~mm}$ i $11 \mathrm{~mm}$. Rupe su bušene na međusobnom razmaku od $64 \mathrm{~mm}$, tj. na svakom uzorku izbušena su po tri provrta $(10 \mathrm{~mm}$, $10,5 \mathrm{~mm}$ i $11 \mathrm{~mm}$ ) u sredini elementa širine $42 \mathrm{~mm}$.

Za potrebe ispitivanja sile izvlačenja dvonavojne su matice uvijane zračnom bušilicom tipa HAZET, pri tlaku zraka od 8 - 10 bara, kao u svakodnevnoj proizvodnji, pri čemu je uvijeno trideset matica po svakom provrtu i vrsti drva, tj. ukupno 270 matica, a za ispitivanje momenta uvijanja korišteno je još 270 provrta.

\subsection{Ispitivanje sile izvlačenja matica}

2.2 Testing the nut extraction force

Uzorci su ispitivani u laboratoriju, na univerzalnoj hidrauličnoj kidalici opremljenoj dodatnom digitalnom mjernom opremom za mjerenje sile i pomaka.

Posebnim načinom učvršćivanja uzoraka u kidalicu simulirano je opterećivanje matica pri upotrebi (sl. 3).

Brzina pomaka glave hidrauličnog cilindra od 5 $\mathrm{mm} / \mathrm{min}$ odabrana je jer je to brzina kojom se u proizvodnji vijkom metričkog navoja metalni kutnici pričvršćuju za drvene elemente.

\subsection{Ispitivanje sile uvijanja i vremena uvijanja}

2.3. Testing the screwing force and elapsed time

Ispitivanje sile uvijanja provedeno je $\mathrm{u}$ industrijskom pogonu, na vertikalnoj glodalici snage $2,2 \mathrm{~kW}$, koja je za potrebe istraživanja dograđena dodatnom digitalnom mjernom opremom (sl. 4). Postolje s dinamometrom spojenim na računalo postavljeno je na radni stol tako da je udaljenost mjerne točke od osi rotacije iznosila $7 \mathrm{~cm}$.

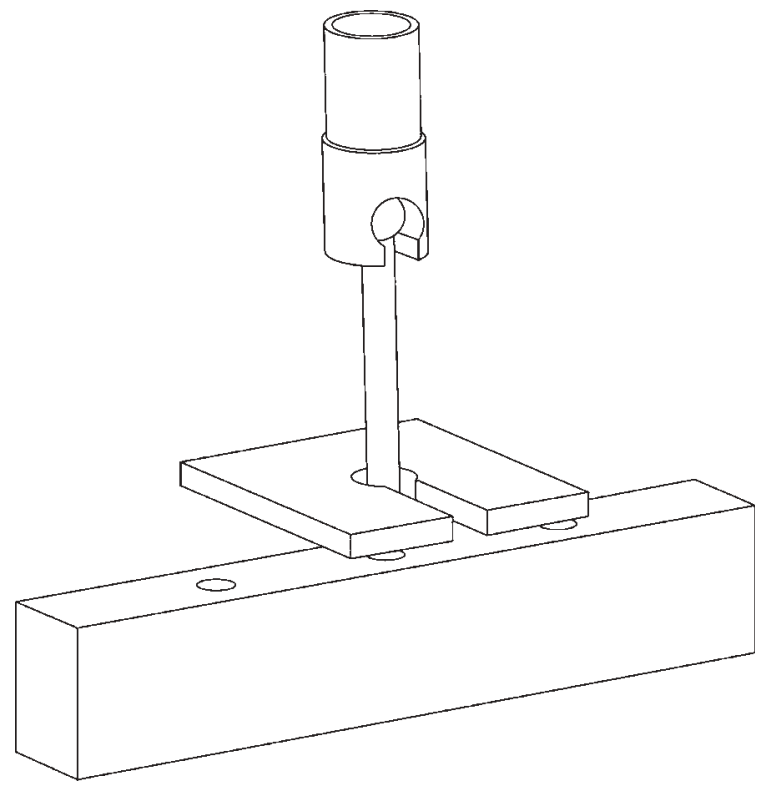

Slika 3. Uzorak sa dodatnim elementima za kidalicu

Figure 3 Sample with additional elements for the tensile test

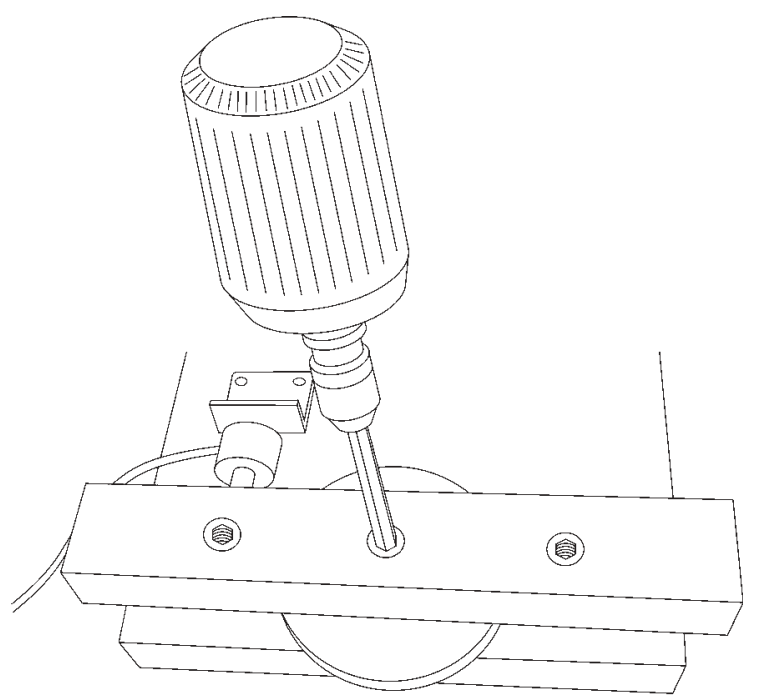

Slika 4. Uzorak pripremljen za ispitivanje momenta uvijanja Figure 4 Sample prepared for torque testing

Mjerenje se obavljalo brzinama 160 i $260 \mathrm{~min}^{-1}$. Brzina $260 \mathrm{~min}^{-1}$ brzina je uvijanja sukladna onoj u pogonu za proizvodnju, a brzinom od $160 \mathrm{~min}^{-1}$ ispitivane su razlike prouzročene smanjenjem brzine.

Vrijeme trajanja uvijanja dobiveno je naknadno, uvidom u mjerne rezultate, tako da je utvrđena vremenska razlika između početne točke, tj. minimalne sile (sila prije prve rastuće točke) uvijanja i maksimalne sile (prva točka prije pada vrijednosti) uvijanja.

\subsection{Obrada i prikaz rezultata}

2.4 Processing and display of results

Prilikom ispitivanja mjereni su iznosi sila i pomaka, a dobiveni su podaci analizirani programima Microsoft Excel i Statistica za Windows platforme.

Za sve analizirane varijable napravljena je deskriptivna statistika (aritmetička sredina, minimum, medijan, maksimum, standardna devijacija), te je za pojedine testove izvršena postotna razlika. Pri svim statističkim analizama pogreška od $5 \%$ smatra se statistički značajnom. U analizi varijance primijenjen je Scheffeov post hoc test, ili je u Kruskal-Wallisovu testu korištena višestruka usporedba rangova srednjih vrijednosti nakon Mann-Whitneyevih testova za analizirane parove grupa (Troendle, 1995; Sokal i Rohlf, 1995).

Grafički prikazi statističke analize rezultata mjerenja izvedeni su u obliku boxplot grafova, dok su ostali rezultati prikazani tabličnim statističkim proračunima. Pri tome je za grupe testirane parametrijskim testovima primijenjena aritmetička sredina i standardna devijacija, a za neparametrijske testove medijan i 25-i i 75-i percentil. Sve su analize rađene uz pomoć statističkog paketa Statistica 7.1 (StatSoft Inc., 2006).

\section{REZULTATI I DISKUSIJA}

\section{RESULTS AND DISCUSSION}

\subsection{Vrijeme trajanja i otpori uvijanju dvonavojnih matica}

3.1 Time consumption and resistance of nut screwing

Promatranjem dijagrama vremenskih promjena mjerenih sila uvijanja triju karakterističnih uzoraka u pro- 


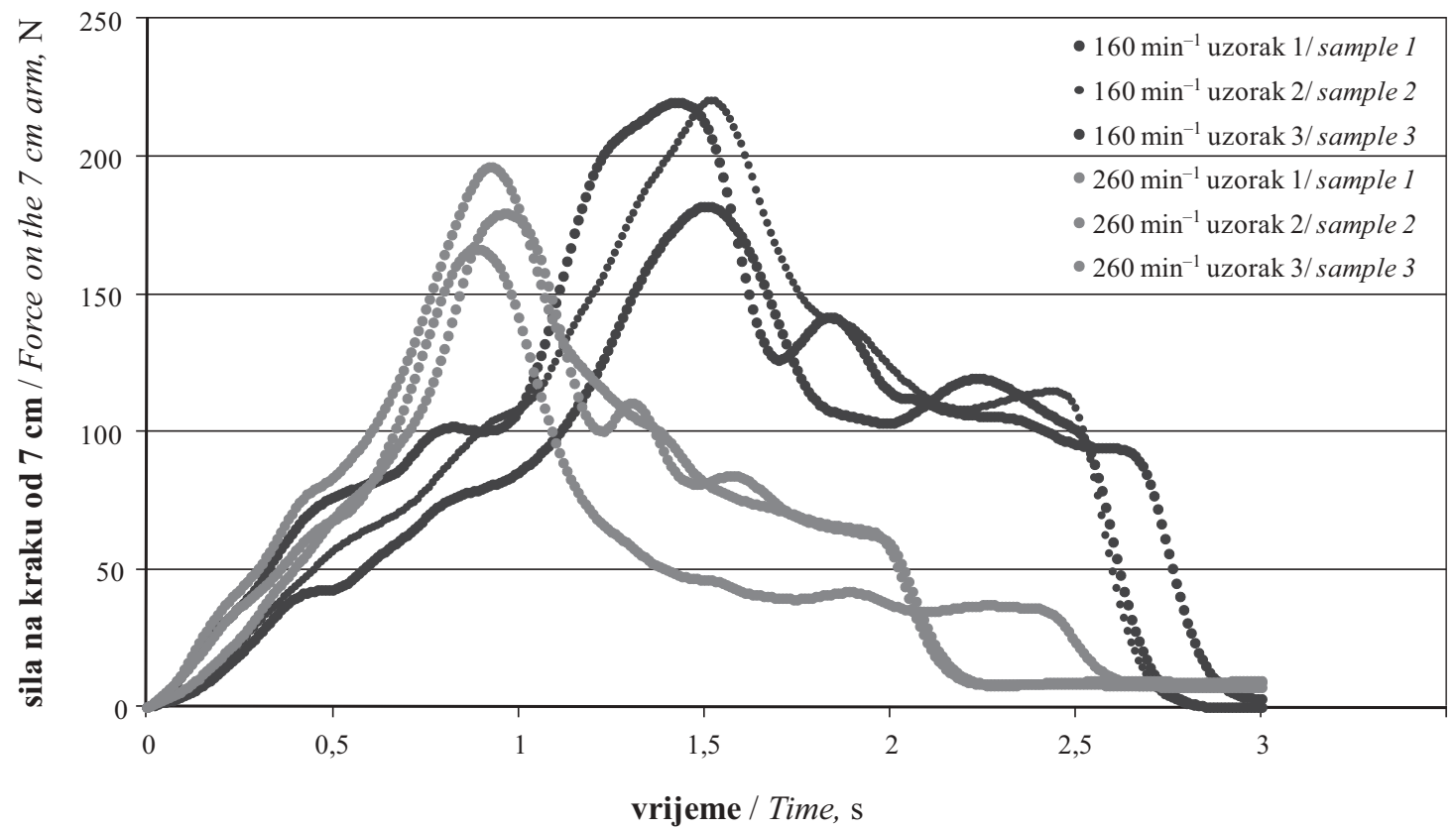

Slika 5. Tri karakteristična rezultata uvijanja matice u bukovinu za promjer provrta $10,5 \mathrm{~mm}$

Figure 5 Tree characteristic results for screwing nuts in beech for $10.5 \mathrm{~mm}$ bore radius

vrte promjera $10,5 \mathrm{~mm}$ jasno su se mogle uočiti razlike u otporu uvijanju koje pokazuju ponašanje matica pri različitim brzinama uvijanja i u različitim vrstama drva.

Iz dijagrama sila uvijanja dvonavojnih matica vidljivo je da mjerena sila pri uvijanju brzinom $260 \mathrm{~min}^{-}$ 1 ima ustaljeniji rast do maksimuma u odnosu prema dijagramima sila pri brzini uvijanja $160 \mathrm{~min}^{-1}$. Iz oblika grafova (sl. 5 - 7) možemo pretpostaviti da pri uvijanju manjom brzinom zbog većeg variranja sile dolazi do nejednolikog narezivanja putanje navoja, što upućuje na nepravilno oštećenje staničja drva, a posljedica toga može biti slabije držanje dvonavojne matice. Prema tome, brzina od $260 \mathrm{~min}^{-1}$ bolja je brzina uvijanja unutar ovih istraživanja.
Jelovina je pokazala očekujuće male sile potrebne za uvijanje matica i rezultat koji nije usporediv $\mathrm{s}$ bukovinom i hrastovinom. Osim toga, pri njihovoj usporedbi može se uočiti da bukovina svojom jednoličnijom građom anatomske strukture postiže veće sile odnosno momente uvijanja od prstenasto porozne hrastovine. S obzirom na to da je gustoća obiju vrsta slična - gustoća standardno suhe bukovine je 490...680...880 $\mathrm{kg} / \mathrm{m}^{3}$ (Trajković i Despot, 1996), a hrastovine 390...650...930 kg/m³ (Petrić i Trajković, 1995) - uz sličnosti nekih mehaničkih svojstava (čvrstoće na tlak, čvrstoće na vlak parelelno s vlakancima), može se zaključiti kako jednoličnija građa osigurava bolji dodir s navojem matice te time i veće trenje.

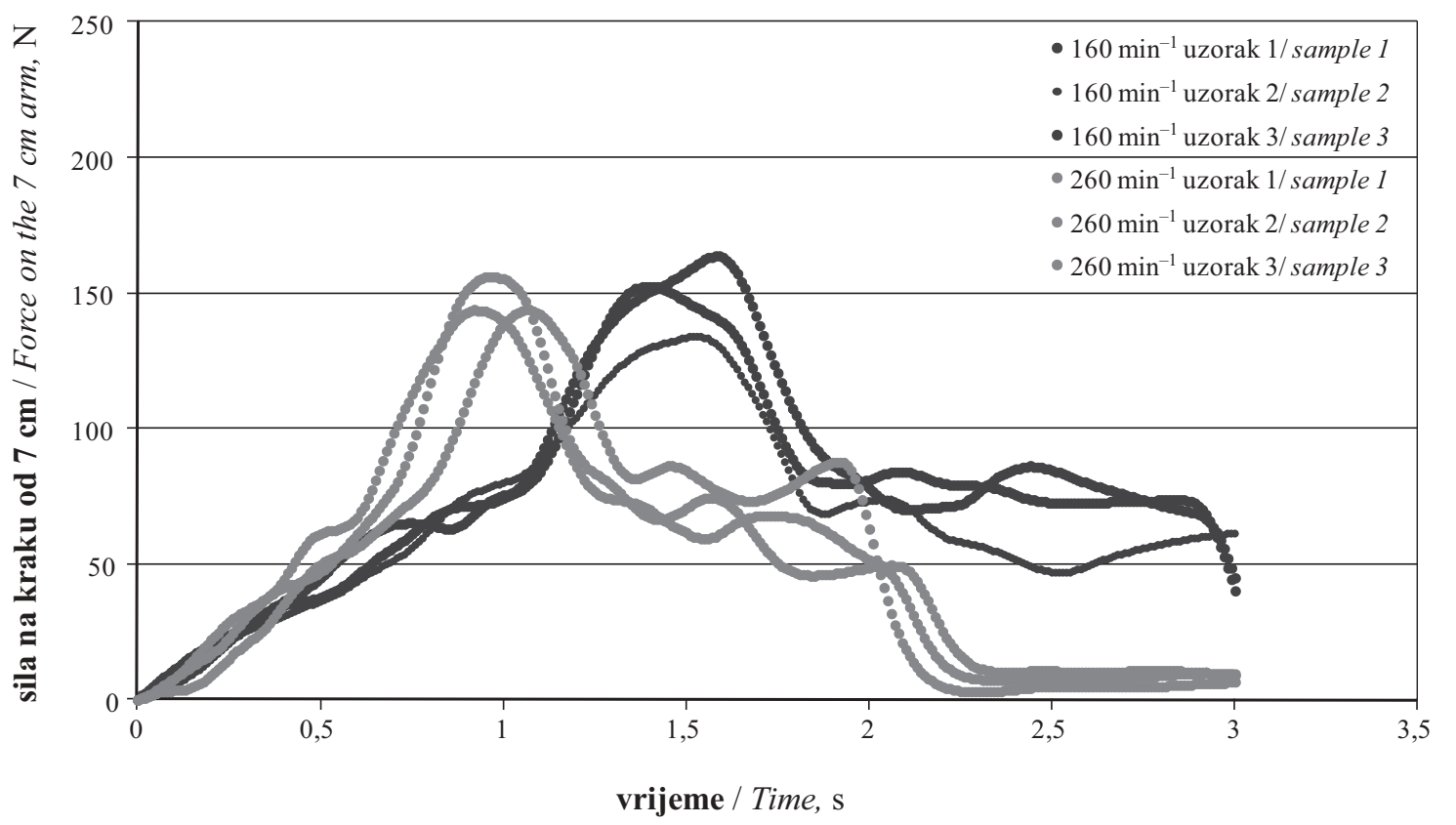

Slika 6. Tri karakteristična rezultata uvijanja matice u hrastovinu za promjer provrta $10,5 \mathrm{~mm}$ Figure 6 Tree characteristic results for screwing nuts in oak for $10.5 \mathrm{~mm}$ bore radius 


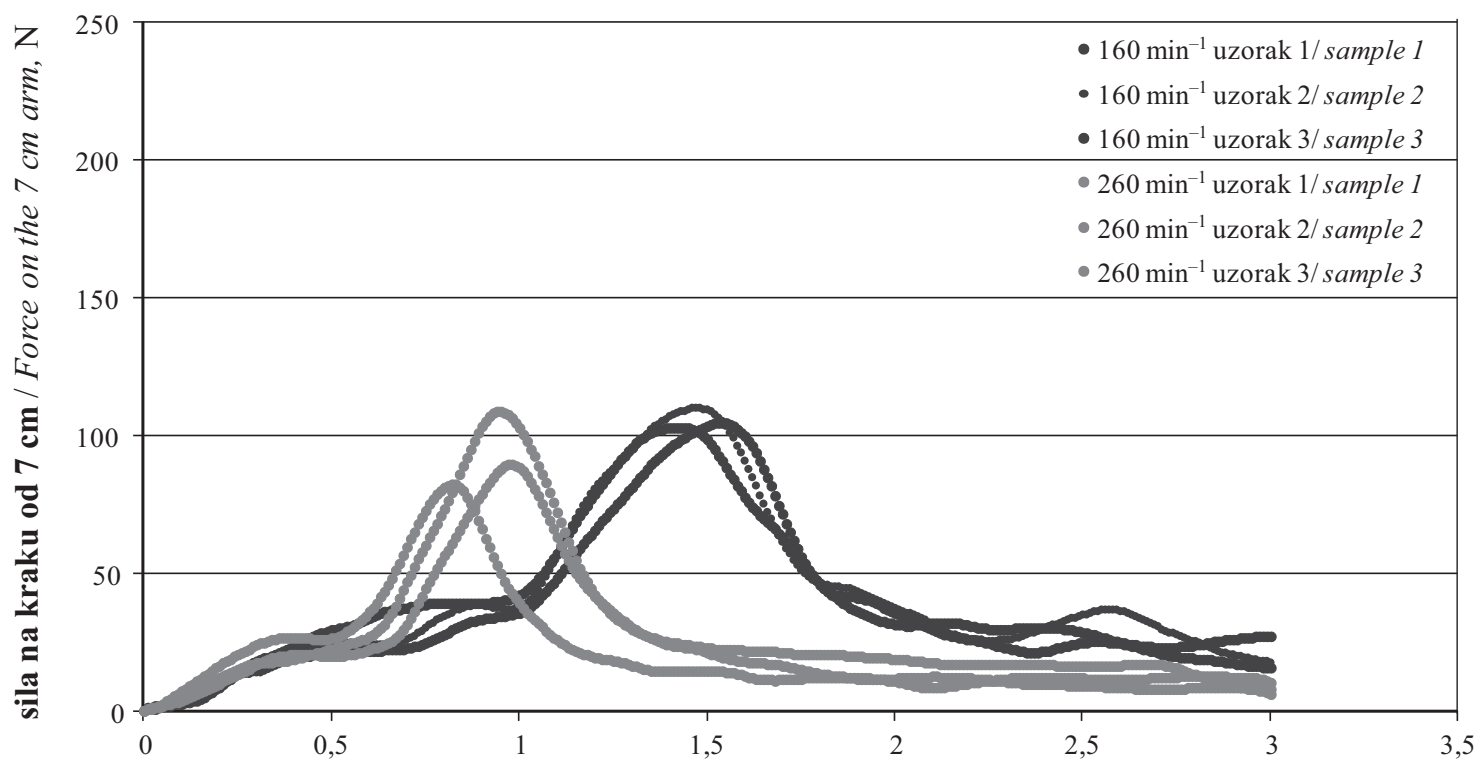

vrijeme / Time, s

Slika 7. Tri karakteristična rezultata uvijanja matice u jelovinu za promjer provrta $10,5 \mathrm{~mm}$

Figure 7 Tree characteristic results for screwing nuts in fir for $10.5 \mathrm{~mm}$ bore radius

3.2. Vrijeme uvijanja s obzirom na brzinu uvijanja

3.2 Screwing time consumption with respect to screwing rate

Pri svakome mjerenju otpora uvijanju dobiveno je i vrijeme uvijanja. Svako mjerenje trajalo je 5 sekundi. Kao početak mjerenja vremena uvijanja uzeto je vrijeme pri kojemu je sila uvijanja počela rasti, a kraj je označavao trenutak kada sila uvijanja počinje padati. Kraj mjerenja vremena ujedno je bio trenutak u kojemu je izmjerena maksimalna sila uvijanja upotrijebljena za izračunavanje maksimalnih momenata uvijanja.

Prosječno izmjereno vrijeme jasno pokazuje da na svim ispitivanim vrstama drva povećanje provrta uzrokuje skraćenje vremena uvijanja. Razlika u rezultatima pri promjeni provrta od 10 na $11 \mathrm{~mm}$ pri brzini od $160 \mathrm{~min}^{-1}$ na bukovini iznosi $20,4 \%$, na hrastovini $20,9 \%$ te na jelovini $19,9 \%$, a pri brzini od $260 \mathrm{~min}^{-1}$ na bukovini iznosi $22 \%$, na hrastovini $21,9 \%$ te na jelovini $28 \%$. Trend produljenja vremena uvijanja jasno je uočljiv, međutim, statističkom analizom tih podataka nije utvrđeno postojanje značajnih razlika $\mathrm{u}$ vremenu trajanja uvijanja matica. Razlika bi nesumnji- vo bila još veća i vjerojatno statistički značajno različita da je za uvijanje upotrijebljena oprema manje snage, na električni ili neki drugi pogon.

\subsection{Usporedba momenta uvijanja pri različitim promjerima provrta i brzinama uvijanja}

3.3 Comparison of torque for different bore diameter and screwing rate

Najuočljiviji rezultat svakako je trend smanjenja momenta uvijanja zbog povećanja promjera provrta. Dobiveni rezultati mjerenja tog momenta pokazuju da međusobne usporedbe na osnovi promjera provrta, bez obzira na vrstu drva i brzinu uvijanja, pokazuju međusobnu statistički značajnu razliku, osim između promjera provrta 10 i 10,5 $\mathrm{mm}$ u hrastovini, pri brzini uvijanja od $260 \mathrm{~min}^{-1}$. Ta se pojava može objasniti samo slučajnim pojavljivanjem nekontroliranih veličina povezanih s procesom uvijanja matica u drvo, na što upućuje veliko rasipanje rezultata (sl. 9). Uz to se može uočiti da su razlike između provrta 10 i $10,5 \mathrm{~mm}$ na svim dijagramima manje nego razlike između momenata pri provrtu 10,5 i $11 \mathrm{~mm}$, čime je dokazano da se idealan provrt nalazi bliže provrtu od $10 \mathrm{~mm}$ nego onome od

Tablica 1. Brzine uvijanja

Table 1 Screwing rate

\begin{tabular}{|c|c|c|c|}
\hline $\begin{array}{c}\text { Vrsta drva } \\
\text { Wood species }\end{array}$ & $\begin{array}{l}\text { Promjer } \\
\text { Diameter } \\
\mathrm{mm}\end{array}$ & $\begin{array}{c}\text { Vrijeme uvijanja pri } 160 \mathrm{~min}^{-1} \\
\text { Consumption time at rate of } 160 \mathrm{~min}^{-1} \\
\mathrm{~s}\end{array}$ & $\begin{array}{c}\text { Vrijeme uvijanja pri } 260 \mathbf{m i n}^{-1} \\
\text { Consumption time at rate of } 260 \mathrm{~min}^{-1} \\
\mathrm{~s}\end{array}$ \\
\hline \multirow{3}{*}{ bukovina /Beech-wood } & 10 & 1,57 & 1,09 \\
\hline & 10,5 & 1,48 & 0,96 \\
\hline & 11 & 1,25 & 0,85 \\
\hline \multirow{3}{*}{ hrastovina / Oak-wood } & 10 & 1,58 & 1,05 \\
\hline & 10,5 & 1,48 & 0,97 \\
\hline & 11 & 1,25 & 0,82 \\
\hline \multirow{3}{*}{ jelovina / Fir-wood } & 10 & 1,61 & 1,00 \\
\hline & 10,5 & 1,46 & 0,91 \\
\hline & 11 & 1,29 & 0,72 \\
\hline
\end{tabular}




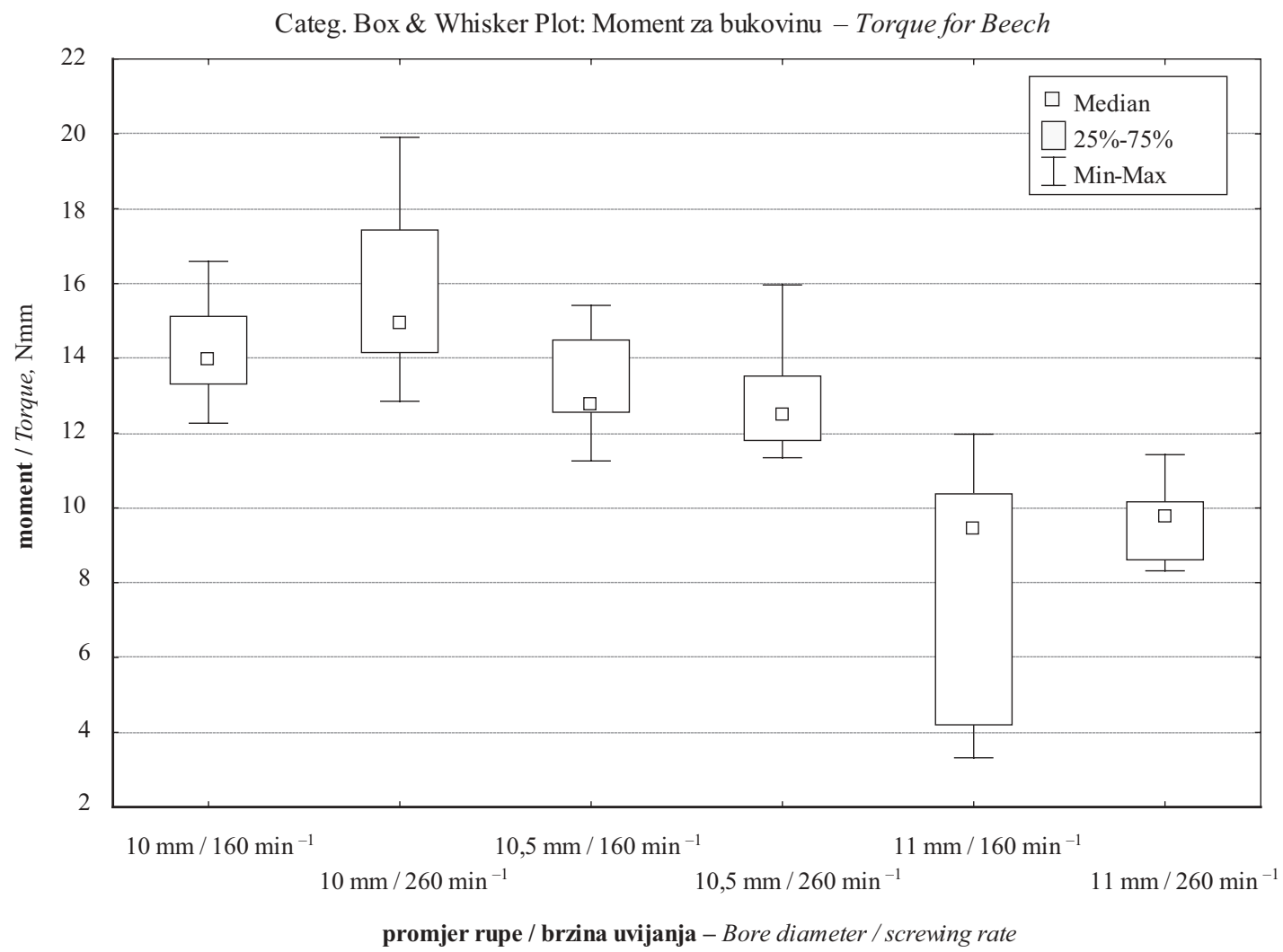

Slika 8. Statistička analiza rezultata izmjerenih momenata uvijanja dvonavojnih matica u bukovinu Figure 8 Statistical analyzes of torque from screwing double thread nuts in beech-wood

Tablica 2. Utvrđivanje razlika za mjerenje momenata na bukovini

Table 2 Determination of differences between torque results on beech-wood

\begin{tabular}{|c|c|c|c|}
\hline \multicolumn{4}{|l|}{ Scheffe test: bukva / Beech (momenti / Torque) } \\
\hline \multicolumn{4}{|c|}{ Razlike značajne za $p<0,05 /$ Marked differences are significant at $p<0.05$} \\
\hline Promjer rupe / brzina uvijanja - Hole diameter / Rotatiom speed & $10 \mathrm{~mm} / 160 \mathrm{~min}^{-1}$ & $10,5 \mathrm{~mm} / 160 \mathrm{~min}^{-1}$ & $11 \mathrm{~mm} / 160 \mathrm{~min}^{-1}$ \\
\hline $10 \mathrm{~mm} / 160 \mathrm{~min}^{-1}$ & & 0,039431 & 0,000000 \\
\hline $10,5 \mathrm{~mm} / 160 \mathrm{~min}^{-1}$ & 0,039431 & & 0,000001 \\
\hline $11 \mathrm{~mm} / 160 \mathrm{~min}^{-1}$ & 0,000000 & 0,000001 & \\
\hline \multicolumn{4}{|l|}{ Kruskal-Wallis test: bukva / Beech (momenti / Torque) } \\
\hline \multicolumn{4}{|c|}{ Razlike značajne za $p<0,05 /$ Marked differences are significant at $p<0.05$} \\
\hline Promjer rupe / brzina uvijanja - Hole diameter / Rotation speed & $10 \mathrm{~mm} / 160 \mathrm{~min}^{-1}$ & $10,5 \mathrm{~mm} / 160 \mathrm{~min}^{-1}$ & $11 \mathrm{~mm} / 160 \mathrm{~min}^{-1}$ \\
\hline $10 \mathrm{~mm} / 260 \mathrm{~min}^{-1}$ & & 0,020143 & 0,000000 \\
\hline $10,5 \mathrm{~mm} / 260 \mathrm{~min}^{-1}$ & 0,020143 & & 0,002746 \\
\hline $11 \mathrm{~mm} / 260 \mathrm{~min}^{-1}$ & 0,000000 & 0,002746 & \\
\hline
\end{tabular}

Tablica 3. Utvrđivanje razlika za mjerenje momenata na hrastovini

Table 3 Determination of differences between torque results on oak-wood

\begin{tabular}{|c|c|c|c|}
\hline \multicolumn{4}{|l|}{ Scheffe test: hrast / Oak (momenti / Torque) } \\
\hline \multicolumn{4}{|c|}{ Razlike značajne za $p<0,05 /$ Marked differences are signifikant at $p<0,05$} \\
\hline Promjer rupe / brzina uvijanja - Hole diameter / Rotatiom speed & $10 \mathrm{~mm} / 160 \mathrm{~min}^{-1}$ & $10,5 \mathrm{~mm} / 160 \mathrm{~min}^{-1}$ & $11 \mathrm{~mm} / 160 \mathrm{~min}^{-1}$ \\
\hline $10 \mathrm{~mm} / 160 \mathrm{~min}^{-1}$ & & 0,021910 & 0,000000 \\
\hline $10,5 \mathrm{~mm} / 160 \mathrm{~min}^{-1}$ & 0,021910 & & 0,000000 \\
\hline $11 \mathrm{~mm} / 160 \mathrm{~min}^{-1}$ & 0,000000 & 0,000000 & \\
\hline \multicolumn{4}{|l|}{ Kruskal-Wallis test: hrast / Oak (momenti / Torque) } \\
\hline \multicolumn{4}{|c|}{ Razlike značajne za $p<0,05 /$ Marked differences are significant at $p<0.05$} \\
\hline Promjer rupe / brzina uvijanja - Hole diameter / Rotatiom speed & $10 \mathrm{~mm} / 160 \mathrm{~min}^{-1}$ & $10,5 \mathrm{~mm} / 160 \mathrm{~min}^{-1}$ & $11 \mathrm{~mm} / 160 \mathrm{~min}^{-1}$ \\
\hline $10 \mathrm{~mm} / 260 \mathrm{~min}^{-1}$ & & 0,167866 & 0,000000 \\
\hline $10,5 \mathrm{~mm} / 260 \mathrm{~min}^{-1}$ & 0,167866 & & 0,000585 \\
\hline $11 \mathrm{~mm} / 260 \mathrm{~min}^{-1}$ & 0,000000 & 0,000585 & \\
\hline
\end{tabular}




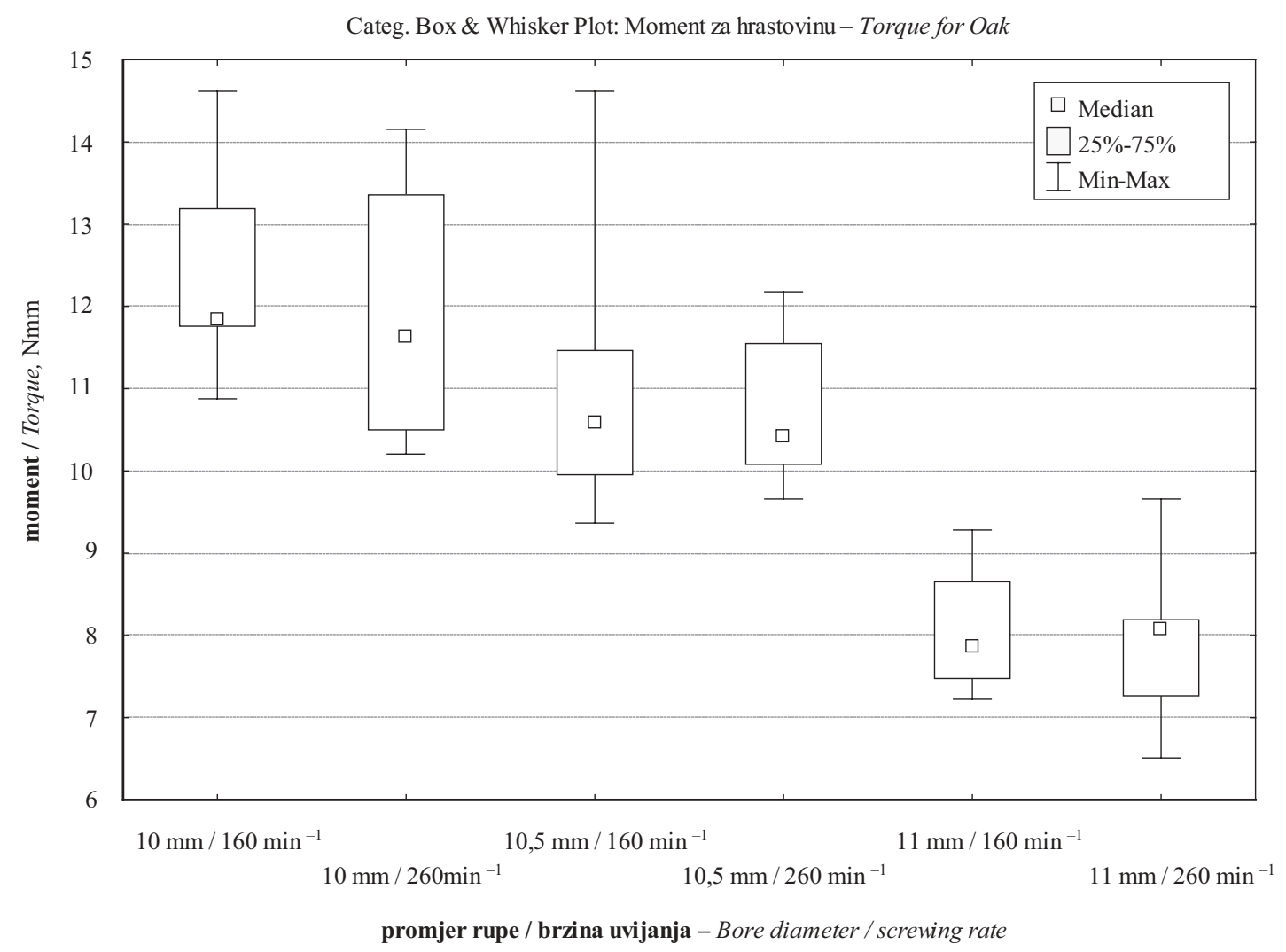

Slika 9. Statistička analiza rezultata izmjerenih momenata uvijanja dvonavojnih matica u hrastovinu Figure 9 Statistical analyzes of torque from screwing double thread nuts in oak-wood

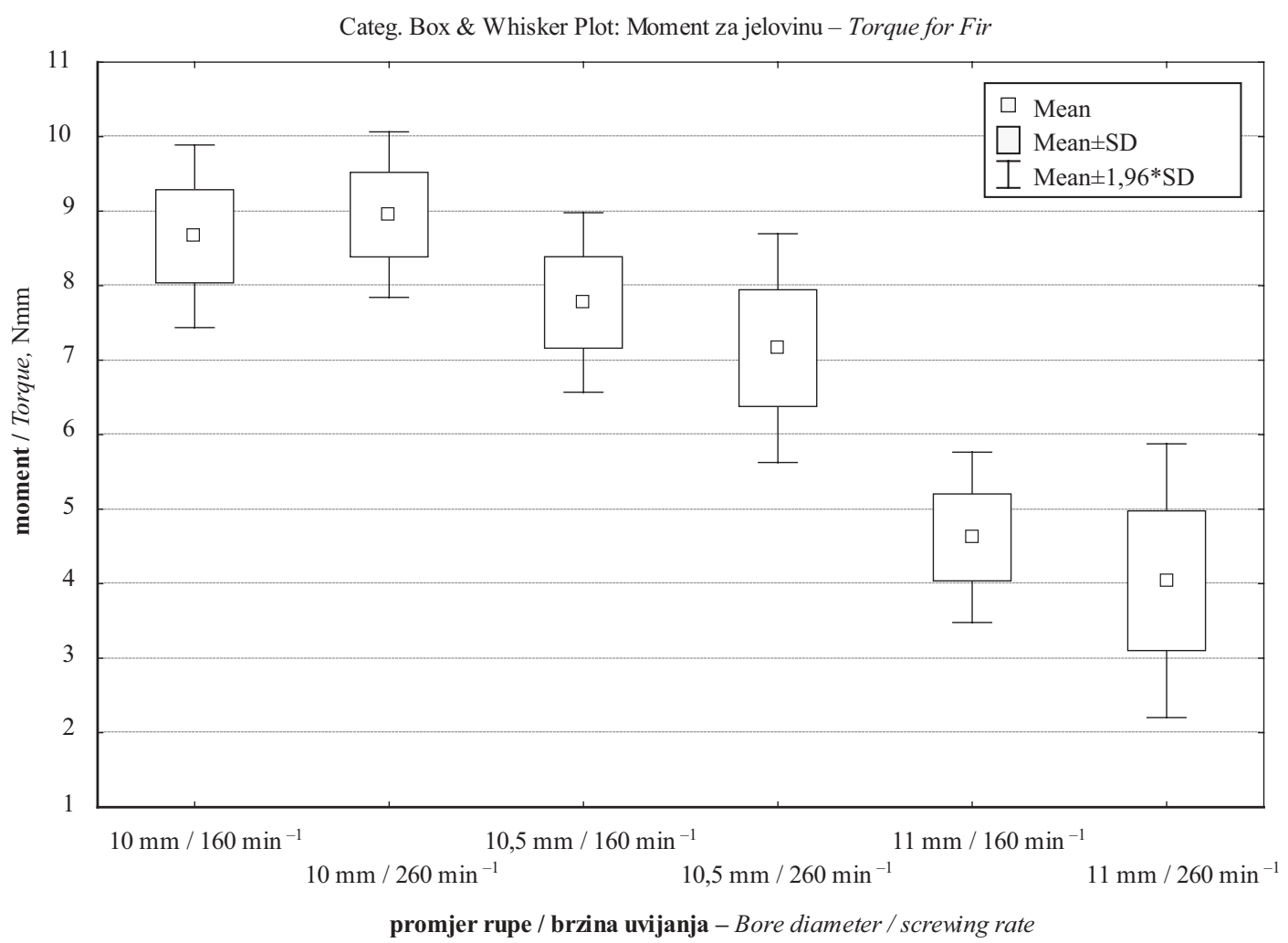

Slika 10. Statistička analiza rezultata izmjerenih momenata uvijanja dvonavojnih matica u jelovinu Figure 10 Statistical analyzes of torque from screwing double thread nuts in fir-wood 
Tablica 4. Utvrđivanje razlika za mjerenje momenata na jelovini

Table 4 Determination of differences between torque results on fir-wood

\begin{tabular}{|c|c|c|c|}
\hline \multicolumn{4}{|c|}{ Scheffe test: jela / Fir (momenti / Torque) } \\
\hline \multicolumn{4}{|c|}{ Razlike značajne za $p<0,05 /$ Marked differences are significant at $p<0.05$} \\
\hline Promjer rupe / brzina uvijanja - Hole diameter / Rotatiom speed & $10 \mathrm{~mm} / 160 \mathrm{~min}^{-1}$ & $10,5 \mathrm{~mm} / 160 \mathrm{~min}^{-1}$ & $11 \mathrm{~mm} / 160 \mathrm{~min}^{-1}$ \\
\hline $10 \mathrm{~mm} / 160 \mathrm{~min}^{-1}$ & & 0,001142 & 0,000000 \\
\hline $10,5 \mathrm{~mm} / 160 \mathrm{~min}^{-1}$ & 0,001142 & & 0,000000 \\
\hline $11 \mathrm{~mm} / 160 \mathrm{~min}^{-1}$ & 0,000000 & 0,000000 & \\
\hline \multicolumn{4}{|c|}{ Kruskal-Wallis test: jela / Fir (momenti / Torque) } \\
\hline \multicolumn{4}{|c|}{ Razlike značajne za $p<0,05 /$ Marked differences are significant at $p<0.05$} \\
\hline Promjer rupe / brzina uvijanja - Hole diameter / Rotatiom speed & $10 \mathrm{~mm} / 160 \mathrm{~min}^{-1}$ & $10,5 \mathrm{~mm} / 160 \mathrm{~min}^{-1}$ & $11 \mathrm{~mm} / 160 \mathrm{~min}^{-1}$ \\
\hline $10 \mathrm{~mm} / 260 \mathrm{~min}^{-1}$ & & \begin{tabular}{|l|}
0,000001 \\
\end{tabular} & 0,000000 \\
\hline $10,5 \mathrm{~mm} / 260 \mathrm{~min}^{-1}$ & 0,000001 & & 0,000000 \\
\hline $11 \mathrm{~mm} / 260 \mathrm{~min}^{-1}$ & 0,000000 & 0,000000 & \\
\hline
\end{tabular}

$11 \mathrm{~mm}$, te da je provrt od $10,5 \mathrm{~mm}$ prihvatljivija supstitucija za provrt od $10 \mathrm{~mm}$.

Osnovna usporedba momenata uvijanja na različitim vrstama drva pokazuje da je za bukovinu potreban najveći moment za uvijanje dvonavojnih matica, a za jelovinu najmanji. Taj se rezultat sam po sebi nameće zbog različitosti u gustoći i tvrdoći drva. Nasuprot tome, bukovina ima znatno veće iznose momenata uvijanja od hrastovine, što pokazuje da moment uvijanja ne raste isključivo s povećanjem volumne mase $\mathrm{i}$ tvrdoće drva. Veći iznosi u bukovine mogu se objasniti većom površinom drva koja je u dodiru s navojem matice zbog većeg udjela drvne tvari u području zone ranog drva nego u hrastovine.

Usporedno promatranje momenata pri različitim brzinama uvijanja pokazuju da povećanje brzine sa 160 na $260 \mathrm{~min}^{-1}$ uzrokuje smanjenje momenata, $\mathrm{i}$ to $\mathrm{u}$ prosjeku od $2 \mathrm{Nmm}$ u bukovine do $1 \mathrm{Nmm}$ u hrastovine i jelovine. Veća promjena u bukovine nego u hrastovine također se može objasniti njezinom ujednačenijom strukturom, zbog čega veća površina drva u dodiru s navojem matice uzrokuje veće trenje. Međutim, treba razmotriti i druga svojstva drva koja mogu utjecati na taj rezultat jer ta primjetna razlika ipak nije statistički značajna, osim za jelovinu na provrtu od $10,5 \mathrm{~mm}$. Uzimajući u obzir iznose značajnosti razlika među rezultatima, može se zaključiti da se razlika momenata između primijenjenih brzina povećava sa smanjenjem mehaničkih svojstava drva.

\subsection{Sile izvlačenja dvonavojnih matica}

\subsection{Results of testing the nut extraction force}

Rezultati ponajprije nedvojbeno pokazuju trend smanjenja sile izvlačenja s povećanjem provrta. Povećanje provrta s 10 na $10,5 \mathrm{~mm}$ donosi 8,9 - postotno smanjenje prosječne sile izvlačenja za bukovinu, što je u odnosu na 53,8 \% smanjenje pri provrtu od $11 \mathrm{~mm}$ zanemarivo. Statistička analiza pokazuje postojanje značajnih razlika između provrta od 10 i $11 \mathrm{~mm}$, kao i između provrta od 10,5 i $11 \mathrm{~mm}$, dok između provrta od 10 i $10,5 \mathrm{~mm}$ razlike nema. Taj rezultat neosporno opravdava primjenu provrta od $10,5 \mathrm{~mm}$ umjesto 10 $\mathrm{mm}$ jer se uz malo smanjenje sile izvlačenja znatno smanjuju momenati potrebni za uvijanje matica, što je dokazano prethodnim mjerenjima (tabl. 2 -4) .

Iako se sila izvlačenja dvonavojnih matica u hrastovine za promjer provrta od 10,5 mm statistički razlikuje
Tablica 5. Razlike sila izvlačenja iz bukovine Table 5 Differences of extraction forces from beech-wood

\begin{tabular}{|l|l|l|l|}
\hline $\begin{array}{l}\text { Scheffe test: bukva / Beech } \\
\text { (sila izvlačenja Extraction force) }\end{array}$ \\
\hline $\begin{array}{l}\text { Razlike značajne za } p<0,05 \\
\text { Marked differences are significant at } p<0.05\end{array}$ \\
\hline $\begin{array}{l}\text { Uzorak / Sample (Promjer } \\
\text { rupe / Hole diameter) }\end{array}$ & $\mathrm{Bu} 10$ & $\mathrm{Bu}+10,5$ & $\mathrm{Bu} 11$ \\
\hline $\mathrm{Bu} 10$ & & 0,293684 & 0,000000 \\
\hline $\mathrm{Bu} 110,5$ & 0,293684 & & 0,000000 \\
\hline Bu_11 & 0,000000 & 0,000000 & \\
\hline
\end{tabular}

Tablica 6. Razlike sila izvlačenja iz hrastovine Table 6 Differences of extraction forces from oak-wood

\begin{tabular}{|l|l|l|l|}
\hline Scheffe test: hrast / Oak (sila izvlačenja / Extraction force) \\
\hline $\begin{array}{l}\text { Razlike značajne za } p<0,05 / \text { Marked differences are } \\
\text { significant at } p<0.05\end{array}$ \\
$\begin{array}{l}\text { Uzorak / Sample } \\
\text { (Promjer rupe / Hole } \\
\text { diameter) }\end{array}$ & Hr_10 & Hr_10,5 & Hr_11 \\
\hline Hr_10 & & 0,000018 & 0,000000 \\
\hline Hr_10,5 & 0,000018 & & 0,000000 \\
\hline Hr_11 & 0,000000 & 0,000000 & \\
\hline
\end{tabular}

od sile pri provrtu promjera $10 \mathrm{~mm}$, možemo primijetiti da je ta razlika od 18,8 \% znatno manja u usporedbi sa smanjenjem od $56,3 \%$ pri promjeru od $11 \mathrm{~mm}$, pa je upotreba promjera rupe od 10,5 mm također opravdana. Može se pretpostaviti da je razlog nastanka statistički značajne promjene između promjera provrta 10 i 10,5 $\mathrm{mm}$ nejednolikost građe prstenasto porozne hrastovine. Naime, moguće je da staničje ranog drva mjestimično omogućuje veće elastične deformacije umjesto potrebnih trajnih deformacija uz navoj matice, zbog čega je njihova izvlačna sila manja nego u jednolično deformiranog staničja bukovine. Takav zaključak potkrepljuje i činjenica da je razlika pri usporedbi momenata pri uvijanju znatno veća između provrta od 10,5 i $11 \mathrm{~mm}$ nego između onih od 10 i $10,5 \mathrm{~mm}$.

$\mathrm{Na}$ uzorcima jelovine sila izvlačenja značajno se razlikuje za sva tri provrta. Povećanje provrta s 10 na $10,5 \mathrm{~mm}$ donosi čak 32,3 - postotno smanjenje prosječne sile izvlačenja, što je u odnosu prema $65,6 \%$ 
- Mihulja, Poljak, Basar: Optimiziranje tehnološkog procesa uvijanja dvonavojnih matica

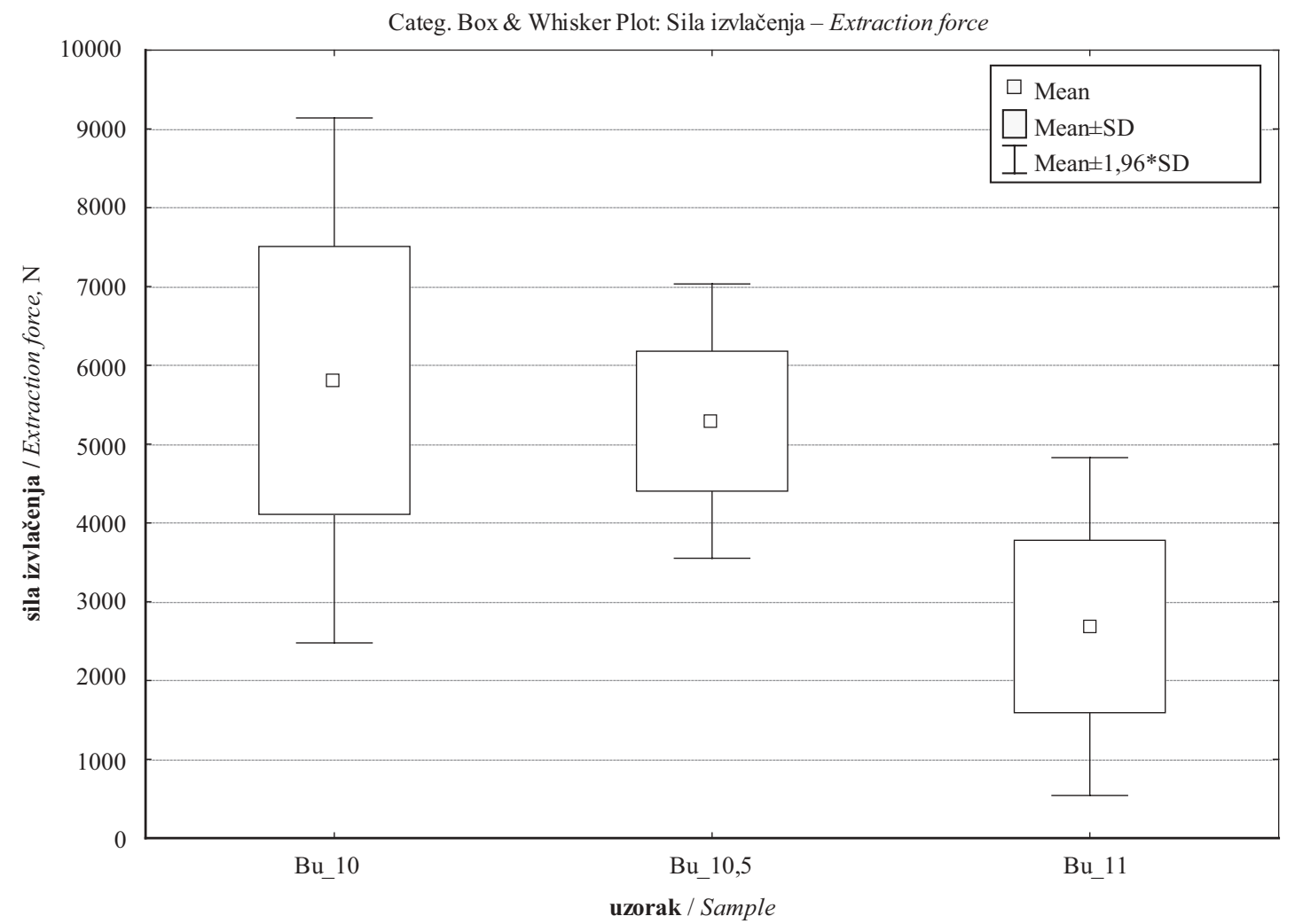

Slika 11. Statistička analiza rezultata izmjerenih sila izvlačenja dvonvavojnih matica iz bukovine

Figure 11 Statistical analyzes of results of measured extraction forces of double thread nuts from beech-wood

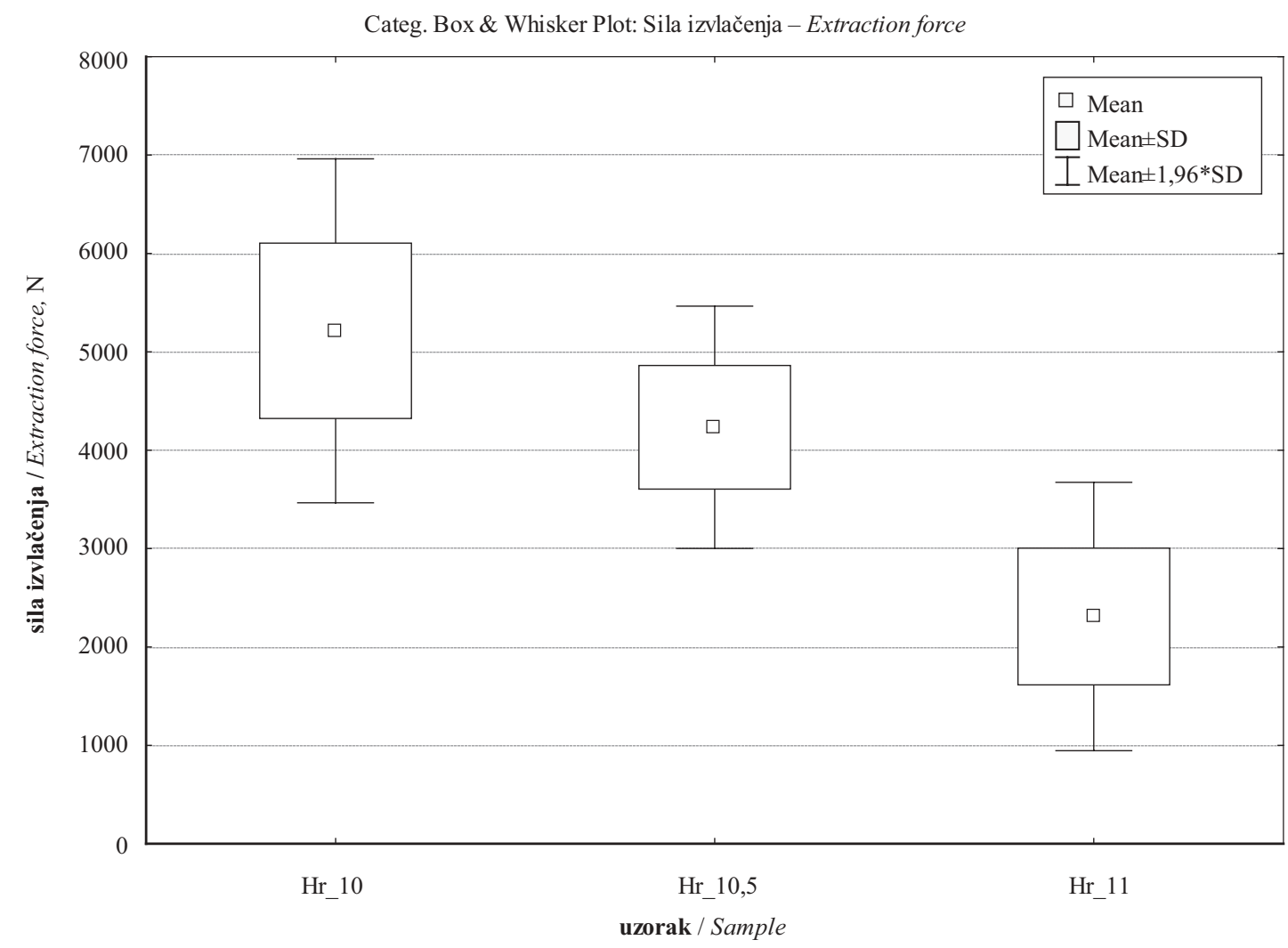

Slika 12. Statistička analiza rezultata izmjerenih sila izvlačenja

Figure 12 Statistical analyzes of results of extraction forces of double thread nuts from oak-wood 


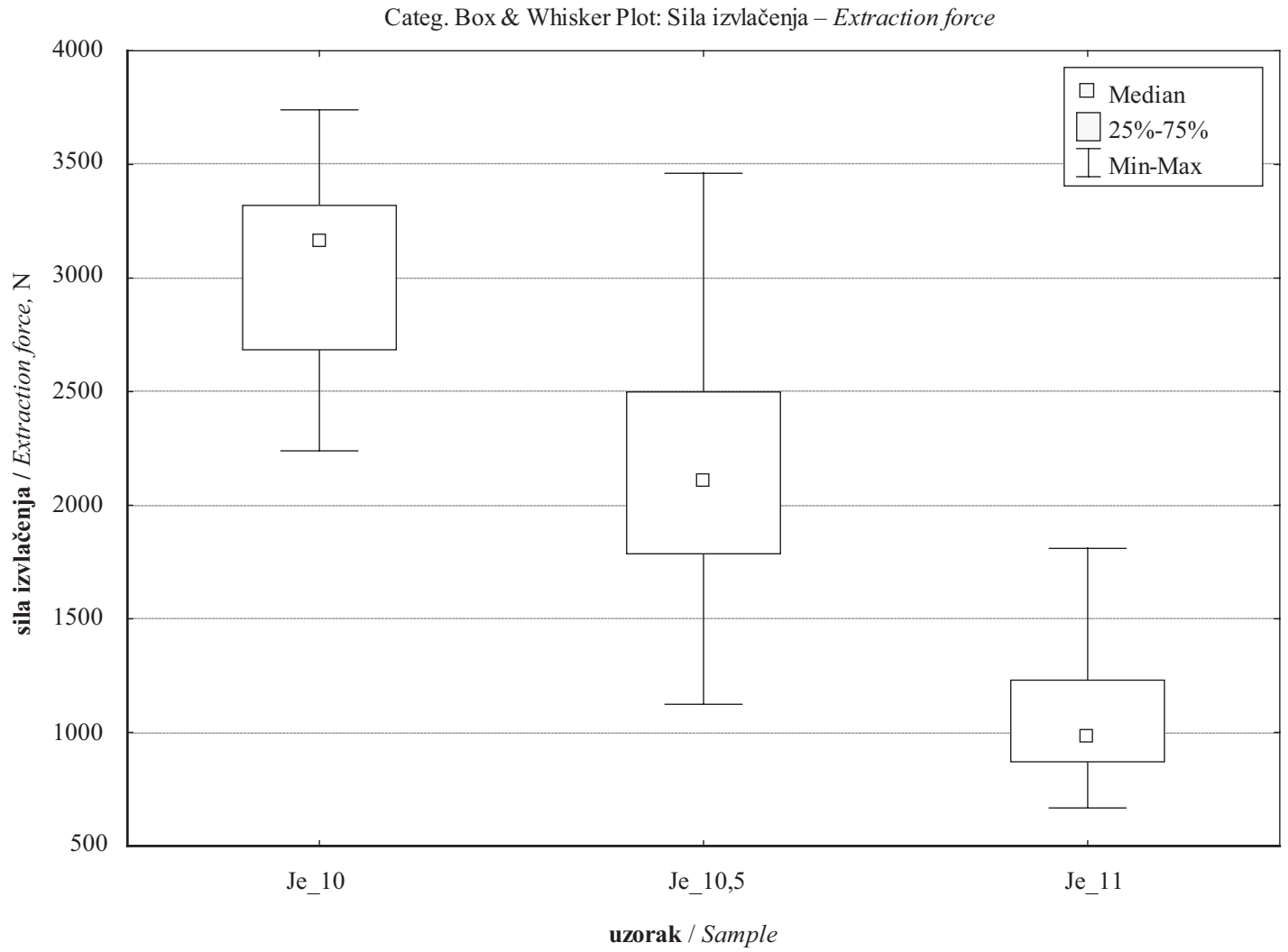

Slika 13. Statistička analiza rezultata izmjerenih sila izvlačenja dvonvavojnih matica iz jelovine Figure 13 Statistical analyzes of results of extraction forces of double thread nuts from fir-wood

Tablica 7. Razlike sila izvlačenja iz jelovine Table 7 Differences of extraction forces from fir-wood

\begin{tabular}{|c|c|c|c|}
\hline Scheffe test: jela & a izvlačen & a-Extract & ion force) \\
\hline $\begin{array}{l}\text { Razlike značajne } \\
\text { Marked difference }\end{array}$ & 05 & $b<0.05$ & \\
\hline $\begin{array}{l}\text { Uzorak / Sample } \\
\text { (Promjer rupe / } \\
\text { Hole diameter) }\end{array}$ & Hr_10 & Hr_10,5 & Hr_11 \\
\hline Hr_10 & & 0,000594 & 0,000000 \\
\hline Hr_10,5 & 0,000594 & & 0,000018 \\
\hline Hr_11 & 0,000000 & 0,000018 & \\
\hline
\end{tabular}

smanjenja pri provrtu od 11 mm upola manje. Sila izvlačenja dvonavojne matice iz jelovine značajno je manja $\mathrm{u}$ odnosu prema silama u bukovini i hrastovini zbog njezinih slabijih mehaničkih svojstava, pa se može zaključiti da za jelovinu nije potpuno opravdano u proizvodnju uvoditi nestandardni provrt od $10,5 \mathrm{~mm}$. Tome pridonosi i činjenica da pri provrtu od $10 \mathrm{~mm}$ moment uvijanja, zbog male čvrstoće drva, ne uzrokuje veće probleme pri uvijanju.

\section{ZAKLJUČAK}

\section{CONCLUSION}

Prosječno vrijeme trajanja uvijanja jasno pokazuje da na svim ispitivanim vrstama drva povećanje provrta uzrokuje skraćenje vremena uvijanja iako statističkom analizom nije utvrđeno postojanje značajnih razlika u vremenu trajanja uvijanja matica.
Povećanjem provrta s 10 na 10,5 mm i povećanjem brzine postiže se skraćenje vremena izrade, a zbog manjih sila odnosno momenata uvijanja smanjuje se i mogućnost oštećenja alata i glave dvonavojne matice.

Smanjenje brzine uvijanja sa 260 na $160 \mathrm{~min}^{-1}$ uzrokuje povećanje momenata uvijanja u prosjeku od 2 $\mathrm{Nmm}$ u bukovine te $1 \mathrm{Nmm}$ u hrastovine i jelovine jer jednoličnija građa bukovine osigurava veći dodir s navojem matice te time i veće trenje odnosno veći otpor uvijanju.

Vremenska promjena mjerene sile odnosno momenata upućuje na zaključak o nejednolikom narezivanju putanje navoja zbog nepostojanog otpora uzrokovanoga nejednolikim deformacijama staničja drva u dodiru s navojem. U ovim istraživanjima uočeno je da brzina od $260 \mathrm{~min}^{-1}$ osigurava kvalitetnije sidrenje matica u drvo odnosno bolju brzinu uvijanja.

Rezultati sila izvlačenja nedvojbeno pokazuju trend smanjenja s povećanjem provrta.

Analizirajući sile izvlačenja, možemo utvrditi da se hipoteza pokazala točnom za bukovinu i hrastovinu. Vidljivo je da ne postoje statistički signifikantne razlike za bukovinu između uzoraka s provrtom od 10 i 10,5 $\mathrm{mm}$, dok se uzorci s provrtom od $11 \mathrm{~mm}$ značajno razlikuju od prva dva. U hrastovine postoji razlika između provrta od 10 i $10,5 \mathrm{~mm}$, međutim smanjenje iznosa sile izvlačenja čini samo trećinu smanjenja zbog promjene provrta od 10 na $11 \mathrm{~mm}$ te se stoga može reći da je smanjenje provrta prihvatljivo i za hrastovinu.

Smanjenje provrta nije opravdano za jelovinu odnosno za vrste drva manje volumne mase jer se time 
samo smanjuje čvrstoća takvog sastava odnosno konstrukcije namještaja. Prema tome, optimizacija tehnološkog procesa za proizvodnju konstrukcija od vrsta drva veće volumne mase, poput bukovine i hrastovine, postiže se uvođenjem nestandardnog provrta od 10,5 $\mathrm{mm}$, čime se veličina sile izvlačenja ne mijenja značajno u odnosu prema promjeru provrta od $10 \mathrm{~mm}$, a postiže se smanjenje momenta uvijanja i skraćenje vremena uvijanja, odnosno procesa proizvodnje te potencijalno visoka razina kvalitete proizvoda.

\section{LITERATURA}

\section{REFERENCES}

1. Grbac, I.; Ivelić, Ž., 2005: Ojastučeni namještaj, Sveučilišni udžbenik, Zagreb.

2. Mihulja, G.; Poljak, D.; Basar, T., 2008: Optimiziranje tehnološkog procesa proizvodnje kreveta od bukovine. Zbornik radova s međunarodne konferencije Drvo je prvo - Svojstva, tehnologija, valorizacija, primjena. Sveučilište u Zagrebu, Šumarski fakultet, Innovawood, Zagreb, 17. listopada 2008, str. 95-101.

3. Petrić, B.; Trajković, J., 1995: Hrast lužnjak. Drvna industrija 46(1): 45.

4. Sokal, R. R.; Rohlf, F. J., 1995: Biometry. Freeman and Company. New York.
5. StatSoft Inc., 2003: Electronic Statistics Textbook. Tulsa, OK: StatSoft. WEB: http://www.statsoft.com/textbook/ stathome.html

6. Tkalec, S., 1983: Metodičko konstruiranje - novi pristup projektiranju i konstruiranju drvnih proizvoda. Drvna industrija, 34(9-10): 219-224.

7. Tkalec, S.; Prekrat, S., 2000: Konstrukcije proizvoda od drva 1. Sveučilišni udžbenik, Zagreb.

8. Trajković, J.; Despot, R., 1996: Bukovina. Drvna industrija 47(4): 171.

9. Troendle, J.F., 1995: A Stepwise Resampling Method of Multiple hypothesis Testing. Journal of the American Statistical Association; 90(429): 370-378, http://dx.doi.org/10.2307/2291163.

\section{Corresponding address:}

Assis. Prof. GORAN MIHULJA, Ph.D.

Department of Furniture and Wood Products Faculty of Forestry, University of Zagreb Svetošimunska 25, p.p. 422 HR-10002 Zagreb, CROATIA e-mail: gmihulja@sumfak.hr 